\title{
○内田真哉（公立南丹病院 耳鼻科）
}

[はじめに］ムンプス㿑患者の 2 万人に 1 人がムンプス難聴を発症するといわれている。10 歳以下での発症が多く、両親が難聴に気づかない場合、早期診断は困難である。今回、発 症初期の臨床経過を捉えることのできたムンプス難聴確実例を含め、平成 10 年の 1 月から 6 月の間に発症した 3 例のムンプス難聴児について報告する。

[症例]

症例 $1: 5$ 歳 女児 (亀岡市)

平成 10 年 1 月上旬ムンプスに罹患、 2 月に左耳痛を訴え、父親が左難聴を疑ったが中耳 炎として近医で加療。3月16日左難聴の精查のため当科へ紹介された。初診時、左耳はほ ぼ能で、ABRは左無反応、カロリックテストでは左右差なく正常。ステロイド等の治療を 行ったが改善しなかった。

症例 $2: 12$ 歳 男児 (亀岡市)

平成 10 年 3 月末に左難聴を訴え、3月 30 日左突発性難聴の疑いで当科に紹介された。本 例は症例 1 といとこ関係にあり、日頃からよく一緒に遊んでいた。即日入院の上、ステロイ ド等の治療を開始したが、翌日に右耳痛出現、翌々日には右耳下腺腫脹、さらに3日目には 左耳下腺腫脹が出現した。初診時、左中等度難聴であったが、急速に進行し壟となった。ム ンプスIgM 13.5から 20.8 と上昇を認めた。

症例 $3: 4$ 歳 男児 (八木町)

平成 10 年 6 月ムンプスに罹患、8月 25 日急に呼びかけに対する反応が悪くなり、8月 26 日小児科を経て紹介された。左耳は先天性の外耳道㹨窄および耳小骨奇形のため生来難聴 であり、今回良聴耳の右耳に発症したと考えられる。ステロイド等の治療を行ったが右耳 聴力は $67 \mathrm{~dB}$ で固定した。左耳聴力は $56 \mathrm{~dB}$ の伝音難聴であり、左耳に補聴器装用を開始 した。ABRは右無反応、左 $90 \mathrm{~dB} に て V$ 波確認、ムンプス IgM 10.3 IgG 38.7 と上昇して いた。

[考按]

$\mathrm{S} 62$ 年厚生省急性高度難聴研究班の診断基準でみると、症例 1 は参考例になるが、これ は難聴に気づかず受診が遅れたためと考えられる。症例 2 はムンプス難聴の特徽的な経過と される急速進行性の難聴を示し、確実例であった。症例 3 は 1 側良聴耳に発症したためか、 幼児例としては早期に難聴が発見された。初診時に残聴が認められたが、幸い進行せずに 固定し、現在奇形のある対側耳に補聴器を装用して効果が得られている。

ムンプス難聴の治療は一般に突発性難聴に準じて行われるが、回復例の報告は少なく、㯖 力予後が極めて不良であるため、ワクチンによる予防が重要である。しかし、現在ワクチ ン接種は任意接種となっており、患者数が増加傾向にあることを考えるとワクチンによる 予防対策の見直しが必要と思われた。 